\title{
Strategic Management at Mormaii - the Brazilian Surf Industry Leader
}

\author{
Marcos Abilio Bosquetti ${ }^{\dagger}$ \\ Federal University of Santa Catarina - UFSC \\ Gabriela Gonçalves Silveira Fiates ${ }^{\Omega}$ \\ Federal University of Santa Catarina - UFSC \\ Jess Ponting ${ }^{\mathbf{X}}$ \\ San Diego State University
}

\begin{abstract}
The sport of surfing has been growing rapidly in popularity worldwide and Brazil is among the countries with the largest surfing population, behind the United States and Australia, however, multinational surf companies are rushing in emerging markets like Brazil to find new opportunities for growth. This paper intends to provide insights on how local companies in these markets can overcome and even take advantage of differences with global competitors by re-thinking their core competencies and business models. Therefore, empirical research applying qualitative case study methodology was developed to investigate the role of strategy in the surf industry - a fairly unexplored research topic. Semi-structured in-depth interviews with the founder and CEO and the executive directors at the Brazilian surf industry leader - Mormaii, were conducted to understand how the 4-decade local company found its way to success. Although the theories: RBV, Core Competencies, and Dynamic Capabilities complement each other and help to explain firms' performance and strategic choices, in empirical studies strategy has been analyzed only by one or another theory. Therefore, the simultaneous use of these three theories intended to fill this gap in the literature and bring more consistency to the discussion of this case study. As a result, this empirical study illustrates the RBV perspective, which stems from the principle that the source of firms' competitive advantage lies in their internal resources and capabilities, rather than simply evaluating environmental opportunities and threats in conducting business. It also highlights the role that core competence and dynamic capabilities play in the company's virtuous circle of sustainable growth and provides practitioners clues for re-thinking their strategies.
\end{abstract}

Keywords: Strategy; RBV Perspective; Sport Business; Surf Industry.

Received in 06/06/2016; revised in 06/25/2016; accepted in 09/11/2016; divulgued in 01/23/2017.

*Author for correspondence:

$\uparrow \mathrm{PhD}$

Institution: Federal University of Santa Catarina

Address: UFSC, Florianópolis, $\mathrm{SC}$, Brazil

E-mail: marcos.bosquetti@ufsc.br
$\Omega . \mathrm{PhD}$

Institution: Federal University of Santa Catarina Address: UFSC, Florianópolis, $\mathrm{SC}$, Brazil E-mail: gabriela.fiates@ufsc.br
¥. $\mathrm{PhD}$

Institution: San Diego State University - SDSU Address: SDSU, San Diego, California - USA E-mail: jponting@mail.sdsu.edu

Note from the Editor: The article was accepted by Bruno Felix.

$($ (c) $)$ BY

This article has a Creative Commons License - Attribution 3.0 Not Adapted. 


\section{INTRODUCTION}

$\mathrm{T}$

The surfer stereotype as an idle and irresponsible guy and surf as counterculture has given way to a growing adoption of surfing as a healthy sport and lifestyle. The search for quality of life, well-being and outdoor sports has transformed surfing in one of the action sports most practiced worldwide (BORNE; PONTING, 2015). According to the Surfrider Foundation (2015) all surfers around the globe celebrate on June 20, the International Day of Surfing, bringing along generations and cultures in appreciation of the surf and the environment.

The International Surfing Association ISA (2013) estimates there are 35 million surfers globally with 5 million surfers only in Brazil, which is among the countries with the largest number of surfers, behind the United States and Australia. In the last few years the rise of professional Brazilian surfers winning world championships has promoted the sport and attracted new practitioners. AlmaSurf (2013) estimates that surf is the second most practiced sport in Brazil, only behind soccer.

The growing number of surf practitioners and supporters transformed the surf industry into a multi-billion dollar business. The Global Industry Analysts (GIA) estimates that the global surf market will reach USD 13 billion in 2017 (GIA 2011). According to The Brazilian Garment Industry Report (SEBRAE, 2015) the surfwear segment alone generates USD 2 billion revenue in Brazil alone. The other surf industry segments include equipment and accessories for surfing like surfboards, fins, leashes, decks, wax, board bags and wetsuits.

Despite the growing number of surfers, the national economic crisis that has plagued Brazil in recent years and the increasing global competition have forced Brazilian surf companies to rethink their strategies.

Multinational surf companies are rushing in emerging markets like Brazil to find new opportunities for growth. While local consumers benefit from the wider choices now available, for the managers of local companies the arrival of giant surf brands appears to be a death sentence. Dawar and Frost (1999) observe that many managers of local companies assume they can respond to the pressure of global competition by becoming a subordinate partner to a multinational or by simply selling out their company and leaving the industry. The authors argue that while multinational corporations can count on a rich literature about how to enter emerging markets, local companies in these markets have had little guidance (DAWAR; FROST, 1999).

Despite the value and potential of the surf industry, a systematic search in academic research databases such as EBSCO and Spell brought out a few articles on "strategy" and "surf" - all related to surf tourism management - reinforcing the Ratten and Babiak (2010) call for more research on this emerging and promising field of study. Therefore, an empirical research applying qualitative case study methodology was conduct to explore the role of strategy in the surf industry and to 
understand how a 4-decade Brazilian company found its way to success by facing stiff foreign competition without becoming a subordinate partner to a multinational corporation in the emerging market of surf in Brazil.

This article investigates the strategic management at Mormaii - the Brazilian surf industry leader to understand how this successful local company faces contemporary threats and consolidates its strengths to take advantage of the opportunities in the emerging market of surf and other action sports in Brazil. This paper uses Resource Based-View - RBV, Core Competencies and Dynamic Capabilities as theoretical framework to discuss the strategic choices that led the company to success. This framework takes into consideration the internal environment of the organization and its resources to understand the source of sustainable competitive advantage, instead of simply the external market positioning through generic competitive strategies.

The RBV theoretical perspective represents the main contribution of the strategic management discipline to the theory of why companies exist and it also helps to explain their performance and strategic choices (GIBBONS, SCOTT; FHIONNLAOICH, 2015), therefore it will support this case study, which may help managers of sport companies from emerging markets gain insight into their own strategic options to overcome and even take advantage of their differences with global competitors.

\section{THEORETICAL FRAMEWORK}

Strategic management is a process for formulating and implementing strategies. It involves the formulation and implementation of the major goals and initiatives taken by a company's top management, based on consideration of resources and assessment of the internal and external environments in which the organization competes (NAG; HAMBRICK; CHEN, 2007). In recent decades many authors have studied how strategy relates to organizational performance (GIBBONS; SCOTT; FHIONNLAOICH, 2015; BARNEY; HESTERLY, 2005; MILLS et al, 2002; BARNEY, 2001, 1995, 1991; HOPKINS; HOPKINS, 1997; BOYD, 1991;PEARCE; FREEMAN; ROBINSON, 1987; PORTER, 1985, 1980; SHRADER; TAYLOR; DALTON, 1984). The development of two theoretical perspectives on strategy (PORTER, 1985, 1980; BARNEY, 1995, 1991) has broadened the understanding of the different levels of performance among industries and companies.

The industrial-organization perspective views the organization's external market positioning through generic competitive strategies - cost-leadership, differentiation or focus - as the critical factor for attaining and sustaining competitive advantage (PORTER, 1985, 1980) while the RBV perspective stems from the principle that the source of firms competitive advantage lies in their internal resources and capabilities, rather than simply evaluating environmental opportunities and threats in conducting business (BARNEY, 1995, 1991). 
RBV is an emerging framework that has stimulated discussion between scholars from different research perspectives (MAHONEY; PANDIAN, 1992). According to Ramos-Rodriguez and RuizNavarro (2004), the RBV theory complements the economic theory and it has been consolidated as the most cited theoretical stream in international journals on strategy since the mid-1990s. Gibbons, Scott and Fhionnlaoich (2015) argue that RBV represents the main contribution of the strategic management discipline to the theory of why companies exist and also helps to explain their performance and strategic choices. Therefore, this case study is supported by the second theoretical perspective, the RBV theory, which takes into consideration the internal environment of the organization and its resources to explain the source of sustainable competitive advantage, instead of simply the external market positioning through generic competitive strategies.

Since the seminal work of Edith Penrose (1959), many others have deepened their insights perfecting and consolidating the RBV theory, particularly the work of Barney $(1991,1995,2001)$.

Barney (1991) examines the link between firm resources and sustained competitive advantage and argues that to have the potential to generate competitive advantage, a firm resource must have four attributes: it must be valuable, in the sense that it exploits opportunities and/or neutralizes threats in a company's environment; it must be rare among a company's current and potential competition; it must be imperfectly imitable; and there cannot be strategically equivalent substitutes for this resource. These attributes are known by the acronym VRIN that stands for Valuable, Rare, Inimitable and Nonsubstitutable.

Collis and Montgomery (1995) further argue that besides the value, rarity, inimitability, and nonsubstitutability of its resources and capabilities, companies should test the durability, appropriability and superiority of its resources and capabilities. Later, Barney and Hesterly (2005) modified the latter feature, so that the non-substitutability was replaced by the Organization $(\mathrm{O})$ Capacity, which means how the company is organized in order to exploit its resources, changing the acronym from VRIN to VRIO.

Newbert (2008) has empirically reinforced the view of resources as the determinants of performance from the heterogeneity among firms and the imperfect mobility of their resources, whether tangible or intangible, such as brand and knowledge.

In addition to the resource-based view, other theoretical dimensions such as the core competence (HAMEL; PRAHALAD, 1994) and dynamic capabilities (TEECE; PISANO; SHUEN, 1997; NELSON, 1991) increased the consistency to the inner strength of the organization as source of sustainable competitive advantage. Therefore, both theories will also be used together with RBV to analyze this case study.

The core competence theory argues that corporate identity is built on its portfolio of skills resulting from collective learning. Thus, core competencies reflect the organization's ability to use 
its resources for a desirable performance (HAMMEL; PRAHALAD, 1994). According to Hammel and Prahalad (1994) core competencies must provide potential access to a wide variety of markets, make a significant contribution to the perceived customer benefits of the end product, and it should be difficult to imitate by competitors.

The dynamic capabilities in turn, deals with the company's ability to rapidly adapt to environmental dynamics and it can be analyzed by its three main elements: adaptive capabilities, absorptive capabilities and innovative capabilities (TEECE; PISANO; SHUEN, 1997). According to Wang and Ahmed (2007), adaptive capacity is the company's ability to identify and capitalize on emerging market opportunities through flexibility and the alignment of its resources in relation to environmental changes. Absorptive capacity reflects the company's ability to identify external relevant information, to assimilate and apply it appropriately, which involves not only the acquisition of external knowledge, but the organization's ability to combine it with internal knowledge for use within the organization. Innovation capacity is the company's ability to develop new products, services, processes and markets through innovation (WANG; AHMED, 2007). Companies with strong dynamic capabilities are intensely entrepreneurial and help to shape the business ecosystems (TEECE, 2007).

It is important to note that the three theories - RBV, Core Competencies, and Dynamic Capabilities - complement each other and help managers to analyze the internal environment of their companies and define their strategies to deal with threats and opportunities from the external environment in order to achieve their strategic intents. In empirical studies strategy has been analyzed only by one or another theory. Therefore, the simultaneous use of these three theories intends to fill this gap in the literature and bring more consistency to the discussion of this case study.

Wright, Kroll and Parnell (1998) argue that companies pursue three basic strategic intentions: growth, stability or retrenchment of their businesses. The growth strategy can be adopted when the organization has the resources and opportunity to increase its market share and the value of its business. The stability strategy prioritizes actions to maintain its market share, since the investment required for growth may be higher than the expected return. The retrenchment strategy is applied when the company realizes it is declining or wants to reduce the scope of its business. The authors highlights that companies may form strategic alliances to grow their business when they do not have the required resources or want to mitigate the risks of investing on a growth strategy (WRIGHT; KROLL; PARNELL, 1998).

According to Dyer and Hatch (2006) companies establish detailed analyzes about their strengths and search for network partners to enable them minimize their weaknesses by complementing expertise and resources. Lavie (2006) argues that the consolidation of companies in social networking 
through alliances is based on the RBV theory to incorporate the network resources of interconnected companies.

Strategic alliance is a partnership between firms whereby resources, capabilities, and core competences are combined to pursue mutual interests (INKPEN; ROSS, 2001). It is developed and propagated as cooperative arrangements that seek to achieve organizational objectives better through collaboration than through competition (HOLMBERG; CUMMINGS, 2009). Todeva and Knoke (2005) present thirteen basic forms of interorganizational relations appearing in the theoretical and research literatures, ordered by their level of legal and social control mechanisms for coordinating the strategic alliance. In between the extremes - from pure market transaction to hierarchical authority relations - lies licensing and franchising as hybrids forms that combine varying degrees of market interaction and bureaucratic integration. In the licensing form of alliance one company grants another the right to use patented technologies or production processes in return for royalties and fees. In the franchising form, the franchiser grants a franchisee the use of a brand-name identity within a geographic area, but retains control over marketing and standardized service norms (TODEVA; KNOKE, 2005).

The increasingly complexity of the environment, characterized by the existence of many interacting variables in a nonlinear way over time (STERMAN, 2000), has led organizations to develop continuously through socially constructed learning processes. In this context, organizations have identified and developed cooperative relationships to achieve competitive advantage (RING; VAN DE VEN, 1992) through win-win game alliances (LUO, 2008).

Von Hippel (1986) points out collaborative relationships with consumers, specially lead users, as another source of innovation and competitive advantage. According to the author, lead users are individuals or organizations who had experienced needs for a given innovation earlier than the majority of the target market and their observations and feedbacks serve as a need-forecasting laboratory for marketing and research \& development providing new product concepts and design that may lead to incremental or radical product innovation (VON HIPPEL, 1986). Recent research highlights the fact that lead users exist not only for products but also for services (SKIBA; HERSTATT 2009, OLIVEIRA; VON HIPPEL, 2011). According to Dawar (2013), the learning from a closer customer interaction creates value that is cumulative and continuously building over time.

Chesbrough (2003) argues that in a world of widely distributed knowledge, companies cannot afford to rely entirely on their own research and should gain knowledge through collaborative relationships. The author promoted the term Open Innovation to refer to the use of both inflows and outflows of knowledge to improve innovation (CHESBROUGH, 2003).

This brief presentation of the main concepts related to RBV, core competencies and dynamic capabilities forms the theoretical framework to discuss the Mormaii case study. 
As Dawar and Frost (1999, p.119) state: "Strategists at multinational corporations can draw on a rich body of work to advise them on how to enter emerging markets, but managers of local companies in these markets have had little guidance." Therefore, this case study illustrates how local companies in emerging markets can overcome and even take advantage of differences with global competitors.

This case study explores the role of strategy in the surf industry and investigates the strategic management at Mormaii - the Brazilian surf industry leader - to understand how this 4-decade Brazilian company found its way to success by facing stiff foreign competition without becoming a subordinate partner to a multinational corporation in the emerging market of surf in Brazil.

\section{METHODS}

This study made use of qualitative data from primary and secondary sources. The methodology guiding research design, data collection, and analysis is the case study. This qualitative research explores the managers' viewpoint in greater depth than quantitative research (EASTERBY-SMITH; THORPE; JACKSON, 2008) and the case study methodology provides a detailed description and analysis of the research topic and the unit of study - the case (YIN, 1984, EISENHARDT, 1989).

The case selected for this exploratory and descriptive study is the Brazilian company Mormaii the pioneer and largest brand of wetsuits for surfing and water sports in Latin America and the leader brand of surfwear in Brazil.

The primary data in this research was collected through semi-structured in-depth interviews with 5 interviewees: the three executive directors of Mormaii (the Founder and CEO, the Vice-President, and the Marketing Director) at the company's headquarter in Garopaba; the managing director of a manufacturer licensed by Mormaii in Garopaba; and the manager of a Mormaii Shop franchisee in Florianópolis. Chronology, the strategic choices and key success factors (resources and capabilities) throughout the history of the organization are the dimensions used to organize the interviews.

Secondary data in the form of reports, news, articles, interviews, and marketing campaigns related to Mormaii and its Founder and CEO Marco Aurélio Raymundo (Dr. Morongo) were collected from a variety of sources: the company's website; business magazines, newspapers, TV talk shows, surf magazines, and surf blogs. This qualitative case study applies content analysis to categorize qualitative data collected from primary and secondary sources and organize it in form of a case study.

\section{RESULTS AND DISCUSSION}

\section{The Birth of Mormaii}

Mormaii was established in 1976 at the garage of Marco Aurélio Raymundo, best known as Morongo in the surfing community. After graduating in medicine in Porto Alegre, capital of the 
State of Rio Grande do Sul, Brazil, Dr. Morongo decided to move to Garopaba - a fishing village in the State of Santa Catarina, where there were no doctors. Morongo says that settling there was a way to help the needy village and enjoy that surfing paradise in a hippie lifestyle (MORMAII, 2015a).

The company started its activities informally when the surfer doctor felt the need to keep his body warm in the cold water of Santa Catarina Winter in 1974. At that time, there was no access to wetsuits in Brazil, so Morongo worked in the community health center of Garopaba and in his spare time he began to design and sew his own wetsuits. Soon he started making wetsuits for friends from Porto Alegre that began to surf in Garopaba especially in the winter season when the swells are bigger and the water colder. Morongo installed a little factory in the garage of his house and began manufacturing wetsuits and thus was born Mormaii - the first wetsuit manufacturer in Brazil (MORMAII, 2015a; EXAME, 2010). The creation of this company can be attributed to the perception of the founder in identifying a gap in the market and consequently a business opportunity. The name of the company, Mormaii, is a word that combines the name of its Founder and CEO Morongo, his first wife Maira and Hawaii.

\section{The company's strategies throughout its history}

Two year after its creation Mormaii moved from the garage to be established initially on the shore of Garopaba, with a small factory and a small shop where the products were sold directly to customers coming from all over the country. In the beginning Dr. Morongo hired his housemaid and three patients with leprosy who had difficulties in finding jobs. However, as the business was growing he felt the need to incorporate people with higher qualifications.

In the 1980s, surfing became a prestigious sport along the Brazilian coast. At the same time, windsurf and kitesurf emerged in Brazil and Mormaii became a national reference in wetsuit for water sports (MORMAII, 2015a). In the beginning there was no competitor manufacturing wetsuits in Brazil, which allowed the company to gain market share and build its brand nationally.

Mormaii developed a growth strategy (Wright; Kroll; Parnell, 2000) over the time. The company built a highly qualified multidisciplinary team to design and develop new lines of products related to actions sports, well-being and surf lifestyle. As an entrepreneur, the founder and CEO of Mormaii, whose education was in medicine, had to improve his management skills to run the growing company. Mormaii invested in the research and development of more flexible and confortable wetsuits. They had searched for suppliers in the United States and Japan, tested and incorporated new materials and features in their products to keep the Mormaii brand as the first mover in the launching of innovations in the surf industry. The design and quality of Mormaii 
products are similar to and in some attributes even better than the products of global brands such as Ripcurl, Quicksilver and Billabong.

The 1990s was a decade of great expansion of Mormaii's product portfolio. The company got into de surfwear segment and adopted internal growth strategies setting up factories for new product lines and increasing its workforce. A comparative study of 12 surfwear companies (FORNECK, 2008) as well as a single case study (BRAZ, 2010), both in the Brazilian surfwear industry, also highlights the use of internal growth strategies.

The company was growing too fast owning and operating several factories with hundreds of employees manufacturing all the company's product lines. At the same time, the giant multinational surf companies started rushing in emerging markets like Brazil to find new opportunities for growth. Therefore, in 1995 the Founder and CEO decided to change the Mormaii business model inspired by biology and the Chinese Yin-Yang symbols. Mormaii adopted horizontal diversification and started developing strategic alliances to manufacture new lines of products by licensing Brazilian companies that had no brand or needed a stronger one to compete in the surf market. Brand extension via licensing has been successfully adopted by the Italian high-end fashion industry to leverage the power of brand reputation and create a constant stream of royalties (COLICCU; MONTAGUTI; LAGO, 2008). Mormaii was the first player in the Brazilian surf industry to use licensing as form of strategic alliance.

The Founder and CEO of Mormaii points out that they conducted a kind of symbiotic process (a close and long-term interaction between two different biological species) and argues that this is part of Yin - the cooperative world. He states "instead of competing against other manufacturers in the industry, we started to cooperate with them by licensing our brand, make other players win as well."

In 1997 the company launched the Mormaii Surf Shop Franchising System. The first franchisee opened a Mormaii Surf Shop at Lagoa da Conceição, in Florianópolis, the Island of Santa Catarina, which is considered the surfing mecca of Brazil and home of several action sport championships. Mormaii developed a unique interior design for its franchisee surf shops providing an atmosphere that resembles a beach house and invites the visitors to daydream by the beach, reinforcing the association of the brand with well-being and surf lifestyle. This innovative interior design concept is based on modular system that allows greater flexibility to change the layout of the store.

In 1998 Mormaii developed its internationalization strategy selling its products to several countries through franchising surf shops and multi-brand stores. It was a response to the arrival of multinational companies in the Brazilian surf industry. Dawar and Frost (1999) observed that local 
companies in emerging markets have successfully adopted extending local advantages abroad as a strategy to compete against giants.

In 2000 the company decided to re-think its business strategy and the alignment between its mission, resources and core competencies to create a sustainable future for the company in the new millennium.

The development of strategic alliances with manufacturing companies enabled Mormaii to focus on branding. The company no longer operates manufacturing facilities. The collaborative relationship with a large number of diversified licensed manufacturers allowed Mormaii to develop five groups of product lines: sporting goods (all kinds of gear and equipment for surfing, kite surfing, skating, mountain biking, diving, including wetsuits and safety accessories); surfwear (t-shirts, shorts, caps, sandals, watches, sunglasses, beach bikinis, handbags, backpacks and accessories); adventure goods (gear and equipment for trekking and camping); lifestyle (beach accessories such as beach umbrella \& chairs, inflatable swimming pool, and beach tennis; music instruments such as guitars and harmonicas, stationery, electronic gadgets accessories made of neoprene like covers for notebooks and smart phones); and fitness (gym equipment, fitness studios, and food supplements).

Following the company's route to provide quality of life, in 2011 Mormaii entered in the service segment, expanding even more its diversified product portfolio. The company designed - in partnership with the athletic coaches of its sponsored team of professional athletes in water sports - a fitness system to improve sports performance and provide the best experience to its consumers, whether they are professional athletes or beginners looking for innovative ways to get fit. In 2012 Mormaii launched the Método Integrado Mormaii Fitness - an integrated fitness training method and a new line of personal fitness equipment for the practice of Pilates, functional, cardio workout and yoga at home including exercise bikes and treadmills, as well as the Mormaii Fitness Studio - an innovative franchising model of studios for physiotherapists and physical education professionals (MORMAII, 2015d).

In order to complement the Mormaii Fitness Solution the company launched in 2013 a product line of food supplements such as cereal bars, whey protein, isotonic, energy drink, açai berry smoothie, sugar free dark chocolate, and even spring mineral bottled water.

In 2016 Mormaii got into the pet market segment launching the innovative Mormaii Pet Accessories such as dog collars and dog breastplate made from neoprene - the same material used in wetsuits, dog leashes made from material used in surfboard leashes, and smart dog feeders designed in surfboard format, everything referring to the surf lifestyle.

Currently, the company has about 5000 items carrying out its brand name produced by 46 manufacturing companies licensed by Mormaii. 


\section{Mormaii's Strategic Resources and Competencies}

The strong reputation of Mormaii brand, its marketing team and its network of strategic alliances form the company's strategic resources and competencies (Barney, 2001; Hamel and Prahalad, 1994):

\section{Mormaii Brand Reputation}

The Mormaii brand has a strong reputation in Brazil and abroad. The brand image is associated to outdoor action sports and a healthy lifestyle. Mormaii started as a surfing brand, later was extended to action sports and more recently has also associated to everything that can promote a healthy lifestyle.

According to the Marketing Director of Mormaii the company invests very little in conventional mass media marketing. Half of its marketing budget is dedicated to sponsoring professional athletes who practice action sports such as surfing, stand-up-paddling, scuba-diving, wind-surfing, kite-surfing, skating, swimming and triathlon. These athletes can be considered lead users that contribute considerably to innovation in product design and development process, as highlighted by Von Hippel (1986).

Sponsorship of sport events such as surf championships - from pro-elite to junior and from national to local events - also takes part of the company's marketing budget to promote the sport and its brand. Furthermore, Mormaii sponsors TV series such as Destino Azul (cruise sailing adventure around the world) and Nalu no Mundo (travel adventures) at Multishow Channel, and a special serial dedicated to surfing: $N a$ Onda (surf trips around the world) at Off Action Sport Channel (MORMAII, 2015e). Sport sponsorship offer potential mutual benefits to both sponsors and sponsees (CLIFFE; MOTION, 2005; COUSENS; BABIAK; BRADISH, 2006).

In the last five years Mormaii has developed a strong social media program focused on sports, health, and well-being. Mormaii provides daily updated news on action sports and many tips and advice on nutrition, workouts, healthy habits and quality of life to almost one million followers on Facebook, Twitter and Instagram (MORMAII, 2015c).

\section{Mormaii's Marketing Team}

Marketing is developed internally in its own marketing agency where all the creation and design - from a simple banner to the packaging of products, advertising campaign for magazines and all the marketing content for the social media - goes through the assessment of the Founder and CEO of Mormaii to guarantee alignment and fit with the company's purpose.

Basically all the people working for Mormaii, including the executive managers, are surfers and part of them also practice a second action sport. As the Founder and CEO of Mormaii states "we 
design and develop products for ourselves". Therefore, the Mormaii's marketing team personally tests all the new products and concepts.

Mormaii also seeks input and feedback from the entire network of licensees and franchisees, involving them in the innovation process (Chesbrough, 2003). Moreover, Mormaii gets feedback from the company's lead users - dozens of sponsored professional athletes - who test Mormaii's products to the extreme conditions of use (Von Hippel, 1986). Besides the close relationship with lead users, Mormaii also has a multi-channel customer relationship management - a CRM system in place that works as a source of feedback on products and customer services provided by the network of licensees and franchisees.

\section{Mormaii’s Strategic Alliances}

The Mormaii's network of alliances is based on long-term cooperative relationships whereby resources, capabilities, and core competencies are combined to pursue mutual interests (Inkpen; Ross, 2001; Lavie, 2006) through a win-win game (Luo, 2008) played with all its licensed manufacturers and franchisee surf shops.

Strategic alliances have proven to be one of the key success factor for Mormaii and its partners in the industry, corroborating the view of Ring and Van de Ven (1992), Wright, Kroll and Parnell (2000), Luo (2008) and Gibbsons, Scott and Fhionnlaoich (2015) on collaborative relationships, because it allows the establishment of strong relationships with all players involved in the network of strategic alliances developed by Mormaii.

For manufacturing partners the alliances allow them to access a large market already developed by the Mormaii branding strategy. For Mormaii, the alliances has brought the possibility to focus on its core competence and capability and implement a new business model to profit from royalties received from each licensed manufacturer and surf shop franchisee for the sale of products carrying out the Mormaii brand.

With this new business model in place, Mormaii expanded, became more organic and focused on its core competence.

\section{Mormaii's Dynamic Capabilities}

The three main elements of dynamic capabilities (Wang and Ahmed, 2007; Teece, Pisano and Shuen, 1997) are identified along the company's trajectory.

The Mormaii adaptive capability is highlighted by the way the company sees possibilities for new market segments, by the development of new products and services to take advantage of all business opportunities not only in the action sport industry but also in the health, fitness and well-being industry. 
The absorptive capability of the company is reflected in its ability to develop and nurture successful relationships and alliances (win-win game) with a range of partners leveraging their strengths and minimizing their weakness by complementing expertise and resource. This dynamic capability enabled Mormaii to develop an open innovation process, as proposed by Chesbrough (2003), by exploring both inflows and outflows of knowledge from suppliers, licensed manufacturers, franchisee surf shops and the sponsored team of professional action sport athletes - the lead users (Von Hippel, 1986).

The innovative capacity of Mormaii is present in almost all its products, services, markets, processes and business models - from the first wetsuit designed in Brazil to the first integrated fitness method and the licensing business model.

Mormaii seems to be an example of what Teece (2007) calls intensely entrepreneurial enterprise with strong dynamic capabilities. Empirical study of small manufacturing companies in Portugal also highlights the influence of resources and capabilities - especially entrepreneurial orientation - on companies' growth (FERREIRA; AZEVEDO; ORTIZ, 2011). In fact, Mormaii's dynamic capabilities led the local company not only to adapt to the presence of global competitors but also shape the business environment through innovation and collaboration with other enterprises.

\section{Mormaii's Virtuous circle of Sustainable Growth}

The new strategy formulated in 2000 was consolidated in 2011 and is marked by the strengthening of its strategic alliances, vast expansion of its product portfolio and the increasingly brand reputation. The three strategic resources have created and leveraged a virtuous circle of sustainable growth.

Currently, Mormaii has 46 licensed manufacturers producing more than 5,000 items carrying out the Mormaii brand. The Mormaii products are available at Mormaii e-commerce website, two owned Mormaii surf shops, 33 Mormaii Surf Shops franchisees and also in more than 20,000 multi-brand retail stores spread out in 80 countries (ÉPOCA, 2015; MORMAII, 2015b).

The company's revenue model is based on royalties. The 46 licensed manufacturers pay around $6 \%$ royalties for the use of the Mormaii brand while the 33 Mormaii Surf shop franchisees pay around 3\% royalties. The product that gave rise to the company - wetsuit - now accounts for only $2 \%$ of the company's revenues. In 2014 Mormaii generated USD 190 million in revenue, growing more than $10 \%$ compared to the previous year. In spite of the current Brazilian economic crises, Mormaii estimates to generate USD 200 million revenue in 2015 (MORMAII, 2015b; ÉPOCA, 2015).

The company's trajectory highlights that Mormaii made use of strategic alliances with other players in the industry, including competitors to focus on the development of its core competencies 
and dynamic capabilities by becoming a lean organization. From almost one thousand employees in 1995, Mormaii has now a team of only 40 people specialized in branding, marketing and licensing. As a lean organization, Mormaii has the focus and agility to rapidly adapt to the increasingly complexity of the environment. The development of alliances to implement its horizontal diversification strategy has also led Mormaii and its network of partners to develop continuously through socially constructed learning processes (Sterman, 2000).

It should be noted that the implementation of these strategies, particularly the strengthening of the brand reputation is also due to an organizational culture that focuses on people and the environment. The executive directors of Mormaii highlight the informal relationship style in the workplace as well as the Mormaii motto: liberdade com responsabilidade (freedom with responsibility), which means that employees have the freedom to go surfing during work to enjoy a swell as long as they are committed to the company's goals. The company's leaders encourage employees to cooperate with each other, not to compete. The Vice-President pointed out that: "the relationship with employees is open and friendly, with no formality in their way of being, dressing and enjoying the Work \& Play environment". The Mormaii's organizational culture, known as the "Mormaii Way", has also been highlighted by national business magazines in the last years (ISTO É, 2016; ÉPOCA, 2015; VOCE S/A, 2013; EXAME, 2010) and attracted talented professionals from São Paulo to join the organization in Garopaba (VOCE S/A, 2013).

Regarding working conditions, the Vice-President states "Mormaii and all its licensed manufacturers and surf shop franchisees must rigorously complies with Brazilian labor laws". These rules were confirmed in the interviews conducted with the licensed manufacturer and the surf shop franchisee.

In order to sustain the Mormaii mission: "To raise the level of awareness of all people who have a relationship with Mormaii" the Founder and CEO of the company argues that the employees and partners of Mormaii must understand in depth the lifestyle proposed by the company and should personally experience it by taking care of themselves, their health, and the environment. He also states "people working for Mormaii are inspired by what the company stands for - quality of life... they are involved in the company's efforts to help make the world a better place: inside and outside Mormaii."

This case study shows the history of a 4-decade old company that has reinvented itself to seize opportunities and reduce the threats of an increasingly dynamic environment marked by global competition. The small garage factory of wetsuit has broadened its product portfolio with such magnitude and diversification and it has become the action sports brand leader in Brazil. 


\section{CONCLUSION}

This case study shows that Mormaii was founded by a surfer doctor and entrepreneur that anticipated a market demand for wetsuits.

The rapid growth of the company was due mainly to the expansion of its product's portfolio that was initially produced by the company that owned and operated several factories with hundreds of employees. Because Mormaii was growing too fast, the Founder and CEO changed the Mormaii business model inspired by biology (symbiosis) and the Chinese Yin-Yang symbols (Ying: cooperation and win-win game, Yang: competition).

Mormaii started to license manufacturers - including competitors - that had no brand or needed a stronger one to succeed in the surf industry. Mormaii focuses on the development of its core competence by becoming a lean organization - from almost a thousand employees to a team of 40 people focused on branding. Mormaii was the first player in the Brazilian surf industry to license its brand.

Currently Mormaii's model of revenue is based on royalties from its strategic alliances in the form of licensing and franchising. The company has about 5,000 items carrying out its brand name, all produced by 46 manufacturing companies licensed by Mormaii.

Mormaii products are available in the Mormaii e-commerce website, its two owned Mormaii surf shops, the franchise network with 33 Mormaii Shops and also in more than 20,000 multibrand retail stores. The Mormaii licensing and franchising system allowed the internationalization of the brand to around 80 countries, making it a global brand as a response to the arrival of giant multinational surf companies in Brazil.

The dynamic capabilities of the Organization have enabled it to understand the external environment and adapt rapidly over time and innovate systematically in all of its processes and products. Those capabilities have been developed throughout its history from their routines and processes, in particular, through learning mechanisms from their internal and external interactions. By re-thinking its core competencies and business model, Mormaii realized that its core competence is related to branding and the ability to promote well-being, health, and life style - all connected to action sports and the nature. This core competence has proven to be valuable to the customers, rare and inimitable (Hamel and Prahalad, 1994), since no global competitors have taken the market leadership from Mormaii.

After growing rapidly as a company owning and operating several factories facilities and almost a thousand employees, the company had to recover its lean shape again to keep its flexibility and explore strategically its core competence to be able to ride the big waves of economic recession and global competition. This case study illustrates the RBV perspective which stems from the principle that the source of firms competitive advantage lies in their internal resources and 
capabilities, rather than simply evaluating environmental opportunities and threats in conducting business (BARNEY, 1995, 1991). It also highlights the role that core competence (Hamel and Prahalad, 1994) and dynamic capabilities (Wang and Ahmed, 2007; Teece, Pisano and Shuen, 1997) play in the Mormaii's virtuous circle of sustainable growth.

Limitations of this exploratory and descriptive case study stand on the fact that findings cannot be generalized to other companies in the surf industry and also on the small group of interviewees, all in management positions. Despite the potential of surfing as a sport, another limitation of this study is the lack of empirical research and market information about the value and scope of the surf industry in Brazil.

Future research is highly recommended for understanding the Brazilian surf industry that still needs to be mapped to know its dimension, stakeholders and the economic, social and environmental impact of this fast growing industry. Research on innovation in the surf industry especially in eco-friendly initiatives as well as on corporate social and environmental responsibility is also recommended to understand the transitions toward sustainability in the sport of surfing, which has been growing rapidly in popularity worldwide.

Further research on the relationship between global surf brands and sport management companies such as the World Surf League - WSL that organizes the world championships is needed to understand how they integrate their marketing strategies and develop partnerships as well as the role that sport associations like the International Surfing Association - ISA and the Association of Surfing Professional - ASP play in the development of the sport industry.

Another exciting further research is related to the impact of artificial waves technology in the surf industry, such as the wave park built by the 11-time world surfing champion Kelly Slater in California, 100 miles away from the ocean and considered the world's best man made wave. The World Surf League - WSL, a global player in the surf event business acquired the Kelly Slater Wave Company to include man made waves on the world championship tour agenda (SURFTODAY, 2016). Future research on the impact of surfing as an Olympic sport is highly recommended, once surfing will be debuting in the Tokyo 2020 Olympic games.

Indeed, the value of surfing as sport to society and its economic, social and environmental impact makes the surf industry in Brazil and worldwide a promising field of research.

\section{REFERENCES}

ALMASURF Nova Era da Transformação: Somos 35 milhões de surfistas no mundo. 17 Abr. 2013. Available: http://almasurf.com/news.php?id=3481, 2013 Retrieved on 17 Set. 2015.

BARNEY, J. B. Firm resources and sustained competitive advantage. Journal of Management, Vol. 17, No. 1, pp. 99-120, 1991. 
BARNEY, J. B. Looking inside for competitive advantage. Academy of Management Executive, Vol. 9, No. 4, pp. 49-61, 1995.

BARNEY, J. B. Resource-based theories of competitive advantage: A ten-year retrospective on the resource-based view. Journal of Management, 27 (2001): pp. 643-650, 2001.

BARNEY, J.; HESTERLY, W. S. Strategic Management and Competitive Advantage: Concepts. Upper Saddle River, New Jersey: Pearson Education, 2005.

BORNE, G.; PONTING, J. Sustainable Stoke: transitions to sustainability in the surfing world. Plymouth: University of Plymouth Press, 2015.

BOYD, B. K. Strategic Planning and Financial Performance: a meta-analytic review. Journal of Management Studies, 28: 353-374, 1991.

CHESBROUGH, H. Open Innovation: The new imperative for creating and profiting from technology. Boston, MA: Harvard Business School Press, 2003.

CLIFFE, S.; MOTION, J. Building contemporary brands: Sponsorship-based strategy. Journal of Business Research, 58, 1068-1077, 2005.

COLlinS, D.; MONTGOMERY, C. A. Competing on Resources: Strategy in the 1990s, Harvard Business Review, 73 (July-August), pp.118-128, 1995.

COlUCCI, M.; MONTAGUTI, E.; LAGO, U. Managing brand extension via licensing: An investigation into the high-end fashion industry. International Journal of Research in Marketing, 25: 129-137, 2008.

COUSENS, L.; BABIAK, K.; BRADISH, C. L. Beyond sponsorship: Re-framing corporate-sport relationships. Sport Management Review, 9(1), 1-23, 2006.

DAWAR, N. Tilt: Shifting Your Strategy from Products to Customers. Boston, MA: Harvard Business Review Press, 2013.

DAWAR, N.; FROST, T. Competing with Giants: Survival Strategies for Local Companies in Emerging Markets, Harvard Business Review, 77 (2) 119-129, Mar-Apr, 1999.

DYER, J. H.; HATCH, N. W. Relation-specific capabilities and barriers to knowledge transfers: creating advantage through network relationships. Strategic Management Journal, v.27, n.8, p. 701-719, 2006.

EASTERBY-SMITH; M. THORPE, R.; JACKSON, P. R. Management Research, 3rd ed. Los Angeles, CA: Sage, 2008.

EISENHARDT, K. Building theories from case study research. Academy of Management Review, V.14, N. 4, p. 532-550, 1989.

ÉPOCA Negócios: Dono da Mormaii dá partes da empresa a funcionários. 26 Sep. 2015 Available: http://epocanegocios.globo.com/Informacao/Resultados/noticia/2015/09/ dono-da-mormaii-dapartes-da-empresa-funcionarios.html. 2015. Retrieved on 28 Sep. 2015.

EXAME Negócios: O Empreendedor Impermanente. 08 Sep. 2010. Available: http:// exame.abril. com.br/revista-exame-pme/edicoes/27/noticias/empreendedor-impermanente-594611. 2010. Retrieved on 20 Sep. 2015.

FAHEY, L.; CHRISTENSEN, H. K. Evaluating the Research on Strategy Content. Journal of Management. vol. 12 no. 2. p. 167-183, 1986. 
FERREIRA, J. J; AZEVEDO, S. G.; ORTIZ, R. F. Contribution of Resource-Based View and Entrepreneurial Orientation on Small Firm Growth. Cuadernos de Gestión, 11.1: 95-116, 2011.

FORNECK, G. R. Os padrões e estratégias de competitividade da indústria de surfwear em Santa Catarina. Monografia submetida ao Curso de Ciências Econômicas da Universidade Federal de Santa Catarina, Florianópolis, 2008.

GIA GLOBAL INDUSTRY ANALYSTS Inc. Surfing: Global Strategic Business Report. San Jose, California: GIA, 2011.

GIBBONS, P.; SCOTT, P. S.; FHIONNLAOICH, C. M. Strategic Management: A perspective on the development of the field of strategic management and the contribution of the Irish Journal of Management. Irish Journal of Management, 34(1) 22-41, 2015.

HAMEL, G.; PRAHALAD, C.K. Competing for the Future. Boston, MA: Harvard Business School Press, 1994.

HELFAT, C.; PETERAF, M. The dynamic resource-based view: capability lifecycles. Strategic Management Journal, 24 (10): 997-1010, 2003.

A. C. Inkpen and J. Ross, Why do some strategic alliances persist beyond their useful life? California Management Review Fall, 132e148 (2001)

HOLMBERG, S. R.; CUMMINGS, J. L. Building Successful Strategic Alliances, Long Range Planning 42(2): 164-193, 2009.

HOPKINS, W. E.; HOPKINS, S. Strategic planning-financial performance relationships in banks: A causal examination, Strategic Management Journal, Vol. 18:8, p. 635-652, 1997.

INKPEN, A. C.; ROSS, J. Why do some strategic alliances persist beyond their useful life? California Management Review Fall, 132-148, 2001.

ISA INTERNATIONAL SURFING ASSOCIATION. Surfing and the Olympics. June 2013. Available: https://www.isasurf.org/olympic-surfing/general-information-olympic-surfing/. 2013. Retrieved on 10 Set. 2015.

ISTO É. Dinheiro: O Negócio é Desapegar, Morô? 27 May 2016. Available: http:// www. istoedinheiro.com.br/noticias/negocios/20160527/negocio-desapegar-moro/377375. 2016. Retrieved on 15 Jun. 2016.

LAVIE, D. The competitive advantage of interconnected firms: an extension of the resource-based view. Academy of Management Review, v.31, n.3, p. 638-658, 2006.

LARAROW, N.; MILLER, M.L.; BLACKWELL, B. The Value of Recreational Surfing to Society. Tourism in Marine Environments, 5(2-3): 145-158, 2008.

LUDWIG, G.; PEMBERTON, J. A managerial perspective of dynamic capabilities in emerging markets: The case of the Russian steel industry. Journal for East European Management Studies, 16(3), 215-236, 2011.

LUO, Y. Procedural fairness and interfirm cooperation in strategic alliances. Strategic Management Journal, 29(1), 27-46, 2008.

MAHONEY, T.; PANDIAN, J. R. The Resource-Based View Within the Conversation of Strategic Management. Strategic Management Journal. Vol. 13, No. 5 , pp. 363-380, 1992.

MILlS, J.; PLATTS, K.; BOURNE, M. RICHARDS, H. Competing Through Competences. Cambridge, UK: Cambridge University Press, 2002. 
MORMAII. Mormaii: A História. 2015a. Available: http://www.mormaii.com.br/a-marca/ historia. Retrieved on 01 Aug. 2015.

. Mormaii: Seja um Franqueado. 2015b. Available: http://www. mormaii.com.br/seja-umfranqueado. Retrieved on 04 Sep. 2015.

. Mormaii Produtos. 2015c. Available: http://www.mormaii.com.br/produtos. Retrieved on 02 Aug. 2015. 2015 .

Mormaii Fitness. 2015d. Available: https://fitness.mormaii.com.br. Retrieved on 02 Aug.

Mormaii Notícias. 2015e. Available: http://www.mormaii.com.br/noticias. Retrieved on 03 Aug. 2015.

. Mormaii Conquistas. 2015f. Available: http://www.mormaii.com.br/conquistas. Retrieved on 01 Aug 2015.

. Relatório de Sustentabilidade: Linha Eco Vibe Mormaii. 2015g. Florianópolis: Casa Mundo Brazil, 2015.

NAG, R.; HAMBRICK, D. C.; CHEN, M. J. What Is Strategic Management Really? Inductive Derivation of a Consensus Definition of the Field, Strategic Management Journal, 28(9), pp. 935-955, 2007.

NELSON, R. R. Why Do Firms Differ, and How Does It Matter? Strategic Management Journal, 12(S2), pp. 61-74, 1991.

NEWBERT, S. L. Value, rareness, competitive advantage, and performance: a conceptual-level empirical investigation of the resource-based view of the firm. Strategic Management Journal, 29: 745-768, 2008.

NIOSI, J. Fourth Generation R\&D: from linear models to flexible innovation. Journal of Business Research, v. 45, n. 2, p. 7-111, 1999.

OLIVEIRA, P.; VON HIPPEL, E. Users as Service Innovators: The Case of Banking Services. Research Policy, 40 (6): 806-18, 2011.

PEARCE, J.; II; FREEMAN, E.; ROBINSON, R. The tenuous link between formal strategic planning and financial performance. Academy of Management Review, 12, 658-675, 1987.

PENROSE, E. The Theory of the Growth of the Firm, London: Basil Blackwell, 1959.

PORTER, M. E. Competitive Strategy: techniques for analysing industries and competitors. New York : Free Press, 1980

. Competitive Advantage: creating and sustaining competitive performance. New York: Free Press, 1985.

RAMOS-RODRIGUEZ, A.; RUÍZ-NAVARRO, J. Changes in the intellectual structure of strategic management research: a bibliometric study of the Strategic Management Journal 1980-2000. Strategic Management Journal, 25: 981-1004, 2004.

RATTEN, V.; BABIAK, K. The role of social responsibility, philanthropy and entrepreneurships in the sport industry. Journal of Management and Organization, 16(4), 482-487, 2010. 
RING, P.S.; VAN DE VEN, A. H. Structuring Cooperative Relationships Between Organizations, Strategic Management Journal, 13(7), pp. 483-498, 1992.

SEBRAE Relatório de Inteligência Sebrae: Vestuário - Moda Surfe. Março 2015. Available: http:// www.bibliotecas.sebrae.com.br/chronus/ARQUIVOS_CHRONUS/bds/bds. nsf/2ccc09cf26e04 ae86cd642d85b11e715/\$File/5401.pdf. 2015. Retrieved on 15 Apr. 2015.

SKIBA, F.; HERSTATT, C. Users as sources for radical service innovations: opportunities from collaboration with service lead users, International Journal of Services Technology and Management 12 (3): 317-37, 2009.

SHRADER, C.; TAYLOR, L.; DALTON, D. Strategic Planning and Organizational Performance: A critical appraisal. Journal of Management, 10(2): 149-171, 1984.

STERMAN, J. Business Dynamics: Systems Thinking and Modeling for a Complex World. Boston: Irwin/McGraw-Hill, 2000.

SURFRIDER FOUNDATION. International Surfing Day - June 20: Protect and Enjoy. Available: http://www.surfrider.org/isd. 2015. Retrieved on 23 Set. 2015.

SURFTODAY. World Surf League buys the Kelly Slater Wave Company. 24 May, 2016 Available: http://www.surfertoday.com/surfing/12807-world-surf-league-buys-the-kelly-slater-wavecompany. 2016. Retrieved on 01 Jun. 2016.

TEECE, D.; PISANO, G.; SHUEN, A. Dynamic Capabilities and Strategic Management, Strategic Management Journal, 18(7), pp. 509-533, 1997.

TEECE, D. Explicating dynamic capabilities: the nature and microfoundations of sustainable enterprise performance. Strategic Management Journal, 28: 1319-1350, 2007

TODEVA, E; KNOKE, D. Strategic alliances and models of collaboration, Management Decision, Vol. 43 (1), 123-148, 2005.

VOCE S/A. Negócios: A Mormaii toca o negócio sem a nóia dos numerous. 13 Jun, 2013 Available: http://exame.abril.com.br/revista-voce-sa/edicoes/181/noticias/sem-a-noia-dos-numeros. 2013. Retrieved on 10 Aug. 2015.

VON HIPPEL, E. Lead Users: A Source of Novel Product Concepts. Management Science, 32, no. 7, pp. 791-805, 1986.

WANG, C. L.; AHMED, P. K. Dynamic capabilities: a review and research agenda. International Journal of Management Reviews, 9 (1), 31-51, 2007.

WRIGHT, P.; KROLL, M. J; PARNELL, J. Strategic Management: concepts. USA: Prentice Hall, 1998.

YIN, R. K. Case study research: Design and methods (1 st ed.). Beverly Hills, CA: Sage Publications, 1984. 